\title{
Trends in Onomastic Research in Brazil
}

Márcia Sipavicius Seide (Paraná) and Marcelo Saparas (Mato Grosso do Sul)

\begin{abstract}
This article brings together recent onomastic investigations developed in Brazil between 2011 and 2018. In the field of toponomastics there is some degree of uniformity resulting from both the use of the same research paradigm and the development of projects dedicated to the production of toponymic atlases in several regions of the country. In the field of anthroponomastics, however, there is dispersion and fragmentation of anthroponymic studies due to non-affiliation with the field by some sociolinguistics and literature researchers The comparison between research papers in this review and a number of onomastic studies in Europe reveals that the socio-onomastic field is an emerging one in both Brazil and Europe. There are investigations that relate the studies of linguistic settings to toponymic studies and socio-anthroponomastic investigations based on data collection in written documents or data generation through field investigations. The existence of comparative anthroponomastic research and studies dealing with theory, methodology and literature review in the field of anthroponomastics can be observed. Studies about Brazilian indigenous onomastics and secondary non-official personal names used by Brazilian city councilors has been found just in Brazil in the literature review presented in this paper.
\end{abstract}

\section{$1 \quad$ Introduction}

Onomastics is the area of linguistics that investigates proper names, which are usually subdivided into names of people (anthroponyms) and names of places (toponyms). The study of distinct characteristics of proper names in western culture goes back to Greek philosophical discussions about the relationship between language and the world. The beginning of onomastic research in Portuguese is attributed to Leite de Vasconcelos, the first philologist to define his object of study in 1928 in Portugal (Vasconcelos 1928: 02); however, these studies only became better known in Brazil with the publication of Dauzat's works (cf. Dauzat 1934, 1945, 1951).

The first toponymic studies in Brazil were carried out at the University of São Paulo (Southeast region) by Carlos Drumond in the mid-1960s. From the 1980s onwards, Maria Vicentina do Amaral Dick (1936), who was advised by him, began to promote this field of research in Brazil (cf. Seabra/Isquerdo, 2018). With respect to anthroponymic studies, the pioneer in the field was Farânio Mansur Guérios (1907-1987) at the Federal University of Curitiba (South region). His dictionary, whose first edition was published in the 1970s, up to this day, is a national reference used by all researchers in the field of anthroponomastics. This article presents trends and perspectives for research in Brazil. First, we introduce some toponymic studies, followed by anthroponymic studies, and then we present studies devoted to personal proper that are not 
indexed by key worlds straight related to onomastics in order to show a more precise overview of what has been investigated in the field of anthroponomastics in Brazil. Finally, the conclusions of this literature review are presented along with a comparison between Brazilian and European investigations.

\section{The tradition of toponomastics in Brazil}

In Brazil, Seabra and Isquerdo clarify that the first investigations on the study of the place names were developed by Carlos Drumond and focused on toponyms originating from indigenous languages. In 1965, he defended his thesis with the title Contribuição Bororo à Toponímica brasílica ${ }^{1}$ at Faculdade de Filosofia Letras e Ciências humanas (FFLCH) at the University of São Paulo (USP). As associate professor, he advised Maria Vicentina do Amaral Dick whose doctoral dissertation made an important contribution to the field: a methodological proposal of toponymic analysis based on a well-founded system of categorization of Brazilian toponyms (cf. Seabra/Isquerdo 2018: 995).

Having become a professor of Linguistics at FFLCH in 1981, Dick was very active in undergraduate courses. She taught two-semester courses on toponymics for undergraduates at FFLCH for decades. Her long-term ideal was to put together a Brazilian toponymic atlas (BTA) by the compilation of regional toponymic atlases, so she initiated a number of toponymic investigations in Brazil by advising undergraduate and graduate students who were encouraged to develop toponymic atlas projects. Among them, Patrícia de Jesus Carvalinhos, who currently teaches the disciplines meantioned earlier at FFLCH. As a result of Dick's endeavour, the consolidation of a paradigm of research occurred and became a classic in the country.

The paradigm that Dick created and consolidated in Brazil is characterized by the adoption of a concept of proper names that considers the discussion of the notion conveyed by language philosophy as a starting point. She claims that although for Mill (1892), proper names would not have lexical meaning, but merely referential functions regarding toponyms there are the motivating character of the toponymic sign and the relation between the name choice, the characteristics of the landscape and the cultural and subjective perception of the landscape by individuals who name the place at stake. In cases where toponyms are not descriptive, she emphasizes the fact that the choice of the name giver is influenced by name givers' values (cf. Dick 1992: 181). Dick maintains that given the specificities of proper names, toponyms and anthroponyms are true records of daily life which, in certain circumstances, functions as linguistics fossils.

Starting from this perspective, the methodological procedures recommended by Dick for the toponomastic research that was adopted in Brazil are: 1) documentary research based on letters produced by the Brazilian Institute of Geography and Statistics (IBGE); 2) data analysis according to the taxonomy of toponymic motivations systematized by her and the geographic and historical context of the region under study; 3) records of data and analyses in standard

\footnotetext{
${ }^{1}$ Bororó Contribution to Brazilian Toponymy.
} 
lexicographic-toponymic forms2 ; 4) Quantitative data analysis (cf. Seide 2013a: 169). Evidently, considering atlas projects, the last step would be cartography. Almost all the atlases mentioned in this paper are focused on county names.

The first research project in this field was developed by Dick herself. It is the project by the name of Toponymic Atlas of the State of São Paulo that began in 1992 (cf. Dick 2004: 127128). Under her supervision, other atlas projects were directly or indirectly created. In the state of Paraná, the project Pelos Caminhos do Paraná: esboço de um Atlas Toponímico ${ }^{3}$ - ATEPAR (1992-2003) was developed. In the state of Minas Gerais, there has been the Toponymic Atlas Project of the State of Minas - (ATEMIG). It has been developed since 2004. The ToponymicHistorical Atlas of the Municipalities of Bahia (ATHMB) was elaborated in 2008. The atlas project Toponymic Atlas of the State of Mato Grosso do Sul (ATEMS) began to take shape in 2012 and includes other kinds of place names other than county names. (cf. Zamariano 2012). In addition to the already mentioned projects, there is a project named Toponymic Atlas Project of the State of Tocantins (ATT), which was organized in 2005 (cf. Andrade 2010: 99). The Toponymic Atlas Project of the Brazilian Western Amazon (ATOB) started in 2006 (cf. Souza, 2008). The Toponymic Atlas Project of Bahia (ATOBAH), whose research began in 2016 (cf. Abade 2016) and the Toponymic Atlas of the State of Maranhão (ATEMA) with partial results published in 2017 (cf. Castro 2017; see table 1).

\begin{tabular}{|l|l|l|l|}
\hline Name of the project & State & $\begin{array}{l}\text { Brazilian } \\
\text { Region }\end{array}$ & $\begin{array}{l}\text { Year the pro- } \\
\text { ject began }\end{array}$ \\
\hline $\begin{array}{l}\text { Toponymic Atlas of the State of São } \\
\text { Paulo }\end{array}$ & São Paulo & southeast & 1992 \\
\hline $\begin{array}{l}\text { Pelos Caminhos do Paraná: esboço de } \\
\text { um Atlas Toponímico }\end{array}$ & Paraná & south & $\begin{array}{l}1992-2003 \\
\text { (finished) }\end{array}$ \\
\hline $\begin{array}{l}\text { Toponymic Atlas Project of the State of } \\
\text { Minas Gerais }\end{array}$ & Minas Gerais & southeast & 2004 \\
\hline $\begin{array}{l}\text { Toponymic Atlas Project of the } \\
\text { Brazilian Western Amazon }\end{array}$ & Amazônia & north & 2006 \\
\hline $\begin{array}{l}\text { Toponymic-Historical Atlas of the } \\
\text { Municipalities of Bahia }\end{array}$ & Bahia & northeastern & 2008 \\
\hline $\begin{array}{l}\text { Toponymic Atlas Project of the State of } \\
\text { Tocantins }\end{array}$ & Tocantins & north & 2010 \\
\hline $\begin{array}{l}\text { Atlas of the State of Mato Grosso do } \\
\text { Sul }\end{array}$ & $\begin{array}{l}\text { Mato Grosso } \\
\text { do Sul }\end{array}$ & mid-west & 2012 \\
\hline Toponymic Atlas Project of Bahia & Bahia & northeastern & 2016 \\
\hline $\begin{array}{l}\text { Toponymic Atlas of the State of } \\
\text { Maranhão }\end{array}$ & Maranhão & northeastern & 2017 \\
\hline
\end{tabular}

Table 1: Brazilian Toponymic Atlases

\footnotetext{
2 These forms have the following fields: location (municipality), toponymy, geographical accident, taxonomy, etymology, morphological structure, history, encyclopedic information, context, source, researcher, reviewer and date of collection.

3 On Paraná Roads: outline of a Toponymic Atlas.
} 
In addition to the referred projects, some initial research has been done in certain areas. In the state of Roraima (in the northern region of the Brazil), there is a toponymic atlas of the indigenous region of Serra da Lua in 2007. In the state of Bahia (in the northeastern region of Brazil) and in the state of Goiás (in the mid-west region of the country), toponymic maps related to the municipality of Quirinópolis were prepared.

Other toponymic surveys based on Dick's paradigm, but not aimed at the development of toponymic maps, have been developed. Research that surpasses this paradigm or uses other paradigms of research is recent. As an example, we cite Lucas's research on the commercial toponyms in Naranjal, a Paraguayan city colonized by Brazilians. In her research, Dick's taxonomy served only as a starting point for more research in the field of toponymy, linguistic landscape and beliefs and attitudes about languages (cf. Lucas 2018). As additional examples of this kind of investigation we can cite: Seide's (2018a) and Seide/Lucas/Teis's (2018) investigations that associate toponymy, linguistic landscape and territory. Their investigation was made in a district called Vila Zelina, a neighborhood located in the city of São Paulo, southwestern region of Brazil, where residents who are Lithuanian or descendants of Lithuanians predominate (cf. Seide, Lucas, Teis 2018, Seide 2018a). Also transcending Dick's paradigm, Carvalhinhos and collaborators, in the period covered by this literature review, published research papers in which they investigate toponymic substitution in the state of São Paulo and its relationship with ideology and politics on the one hand, and issues of preservation of collective memory, on the other (cf. Carvalhinhos/Lima 2013, 2014, 2018, Carvalhinhos/Lima-Hernandes/Lima 2018, Carvalhinhos 2018).

Due to Dick's innovative and pioneering role and the research she has promoted in Brazil, it can be said that the field of toponomastics has been consolidated. The same has not occured with anthroponomastics. There is great disparity between the fields of anthroponomastics and toponomastics. Regarding anthroponomastic research, there are no such unified research groups in Brazil, but some embryonic niches (cf. Seabra/Isquerdo 2018: 995f.).

\section{$3 \quad$ Studies affiliated with Anthroponomastics}

In Brazil, anthroponomastic studies were initiated by Rosário Farâni Mansur Guérios. He was a professor at the Faculty of Philosophy, Sciences and Language of the Federal University of Paraná (UFPR) since 1939. In 1975 he published the first edition of his etymological dictionary, whose last edition, which was revised and extended, dates from 1981 (cf. Guérios 1981). This work became a national reference and has been used by a number of Brazilian scholars affiliated with the anthroponomastic field. Despite the relevance of this dictionary, Guérios, unlike Dick, did not train researchers in the field, which may be due to the fact that the post-graduation program in Linguistics ${ }^{4}$ at UFPR was founded in 1988, after his death.

A literature review of a sample of papers presented at the ICOS Congress of 2011, held in Barcelona, indicated the existence of the following areas of anthroponomic study: socio-

\footnotetext{
${ }^{4}$ In Brazil, as a rule, language research is not funded by research centers, but rather by postgraduate programs. Researchers who are not involved in such programs can develop individual projects, but rarely obtain financial or institutional support, which have been directed to the programs and researchers who, taking part in these programs, publish more articles in the field.
} 
anthroponomastics (a part of socio-onomastics), fictional anthroponomastics, comparative antroponomastics, anthroponomastics applied to translation studies, historical anthroponomastics and anthroponomastics, linguistic policies and legal framework (cf. Seide 2016). In addition to the cited areas, there are also studies that focus on unofficial and secondary anthroponyms, which belong to the category of allonyms (cf. Amaral 2011), and those whose main research objects are concerned with theory, methodology or literature review in the area.

Nolasco and Hosokawa (2012), Mariano (2013), Almeida (2015) and Rodrigues/Coelho (2016) published research papers investigating first names from a historical point of view. Almeida worked on elucidating how Greek first names present in the Brazilian anthroponymy are analyzed and described in an etymological onomastic dictionary of names by the Portuguese philologist João Pedro Machado (1981, 2003). Also, based on etymological and historical lexicographical information, Rodrigues and Coelho (2016) attested to the existence of first names of Germanic origin in the anthroponymy of the state of Bahia (in the northeastern region of the country), as a late consequence of the influence of the Visigoths and the Suevi in the Middle Ages in Portugal. In addition, they confirmed that such influence in that region is not due to any more recent contact between the population of Bahia and the population of Germanic origins 5 .

Sacerdote (2012) conducted a study on medieval Portuguese surnames based on a corpus of 168 Portuguese notary documents. Mariano (2013), in turn, dedicated himself to the study of first names, middle names and last names of Afro-descendants from the state of Bahia that were enrolled in a society of social protection throughout the 1920s. Nolasco/Hosokawa (2012) analyzed the mentioned anthroponyms in a corpus of family letters from an influential politician from the state of Acre (northern region) written between the 1950s and the 1970s. In addition to a historical point of view, the philological method was employed in all the studies cited so far.

Vescovi also analyzed data from the municipality of Palotina and Maripá, located in the western part of the state of Paraná (southern Brazil), in order to show the impact, in these municipalities, of an immigrant movement motivated by the planting of mint in the 1970s concerning the register of first names and surnames in birth certificates (cf. Vescovi 2016). Other anthroponymic descriptions of the same region covering the period of formation of municipalities of western Paraná up to the current date (in the 1960s and 2000s) were carried out in municipalities in the same sub-region of the state of Parana: Toledo (cf. Seide/Grespan 2013, Grespan 2014), Palotina and Maripá (cf. Vescovi 2014, 2015) and Marechal Cândido Rondon (cf. Seide 2014, 2018b, 2018c). These surveys followed the same paradigm: data collection of first names was based on a sample of birth certificates drawn up in the respective municipalities (selection of the first 100 records of each decade) and data analysis was done to try to find out correlations among linguistic features (most frequent names in each locality, changes in anthroponymic repertoire over time, orthographic and morphological variation of names and preference for the

\footnotetext{
5 The presence of Germanic names in the southern region of the country, however, is on account of the coexistence of Germans or people of Germanic origin and populations of other origins, considering that the region was colonized, among others, by Germanic migrants and their descendants from the late nineteenth century. At the same time, many Italians and Poles also migrated to the region.
} 
use of compound names), the history of colonization, demographic changes and cultural characteristics of the region. It should be noted that, although etymology of surnames was the subject of two of these studies (cf. Grespan 2014, Vescovi, 2016), the analysis of first names was emphasized.

Other investigations were carried out aiming at analysis of first names in the municipality of Marechal Cândido Rondon, but based on field research with data collection through interviews, questionnaires and reports involving university students and focusing on the motivation of first names (cf. Seide/Frai 2016, Frai 2016a, Seide 2013b, 2013c, 2016a).

Anthroponymic analyses and descriptions of two municipalities of the state of Rio Grande do Sul, southern region of the country, were also carried out: Lajeado (Eckert 2013) and Bento Gonçalves (cf. Eckert 2016, 2017). The investigations were based on the etymological analysis of both first names and surnames. In reference to the latter, the analysis correlated their etymological origin with the migratory movements of Europe (mainly from Italy and Germany) to the region. There was also the analysis of the anthroponymy of the municipality of Estrela, following the same methodology, but having telephone directories of the municipality (cf. Eckert/Röhrig 2016b) as data source.

Research papers that gathered previous research on the repertoires of personal names of several indigenous languages and respective name giving processes were also published. In these surveys, the naming systems of each language and cultural, historical and anthropological values linked to them were emphasized. Martins et al. (2018) described and analyzed the anthroponymy $^{6}$ of the Kaiowá language, whose speakers live in the region near the Xingu River in the state of Mato Grosso do Sul, while Fargetti (2018) dedicated himself to the Juruna anthroponymy whose speakers live near the Xingu River, in the state of Mato Grosso.

Dias (2018) gathered information from several indigenous anthroponymic systems: an anthroponymy of the Arawete language, whose speakers live in the indigenous area by the Xingu River, in the northern state of Pará; anthroponymy of the Amondáwa language, whose speakers live in an Indian reservation in the state of Rondônia (northern region of the country); anthroponymy of the Xavante language, whose speakers live in several villages in the state of Mato Grosso (mid-west region); anthroponymy of the Xerente ${ }^{7}$, whose territory is located in the State of Tocantins (northern region); anthroponymy of the Pirahã language, whose speakers live in the state of Amazonas (northern region), anthroponymy of the Tapirapé language, whose speakers live in two indigenous areas located in the state of Mato Grosso; and the anthroponymy of the Xetá language.

Specifically on Xetá anthroponymy, Dias emphasized that the descendants of the speakers of this language are dispersed in different indigenous areas in the states of São Paulo (in the southeastern region) and the neighboring states of Paraná and Santa Catarina (in the southern region

\footnotetext{
${ }^{6}$ Descriptions of indigenous person name system do not always match the western personal names categorization. Due to this fact, it is more appropriate to refer to them more vaguely as anthroponymy.

7 Studies of the historical records of the Xerente show that they and the Xavante, in the past, formed one people and one language (cf. Dias 2018: 265).
} 
of the country). These descendants are currently in the process of recovering their culture, language, and naming system (cf. Dias 2018: 255).

Falchi and Aguiar (2018) described the anthroponymy of Noke Koin, whose speakers live near the Juruá River in the Amazon region of the state of Acre (northern region of the country). He also described the mythology of this indigenous people, whose culture and language have received influence of the Brazilian majority culture in general and, especially, of the protestant missionaries who have carried out their activities there under the auspices of the United Nations organization New Tribes Mission of Brazil (MNTB) since 1972 (cf. Falchi/Aguiar 2018: 327f.). There is also a semantic study about the antroponymic system of Parkatêjê language spoken by indigenous people of Amazon region (cf. Lopes/Ferreira 2018).

As mentioned, research dealing with indigenous anthroponyms is concerned both with the repertoire of person names and with the process leading to the choice of the anthroponym, viz., the anthroponymic process and products. On the anthroponymic selection process we can find some studies about the Portuguese language of Brazil. In this scope of research, we find Frai's research and Frai/Seide's investigations (cf. Frai/Seide 2015, Frai 2016a) on the motivation to choose a second personal name to name residents in the municipality of Marechal Cândido Rondon and also Seide's investigations based on questionnaires applied to college students born during the 1990s and that were signed up for a degree in Language at the State University of the West of Paraná, at the Marechal Cândido Rondon campus. In Seide`s study, firstly the motivations cited by undergraduates were analyzed (cf. Seide 2013b, 2013c) and then there were refinements to analyze the choice of first name for religious motivation in the region (cf. Seide 2016a), while Frai analyzed the motivations that lead residents of the municipality of Marechal Cândido Rondon to choose a second name for their children based on data generated through semi-structured interviews (cf. Frai 2016).

In another investigation, Seide compared the process of anthroponymic choice in monolingual contexts with the process in plurilingual contexts and related them to migratory processes related the former to the Japanese migration in Brazil and the latter to the naming processes described by Aldrin (2017) with respect to migrants in present-day Sweden (cf. Seide 2013c). Other investigations in this sub-area of anthroponomastics have been carried out: while Cardoso traced back to the 16th century and compared the Portuguese and indigenous onomastic systems of the Tupi branch in Brazil in order to clarify cultural issues involved in the christianization initiated by the Jesuits (cf. Cardoso 2018), Seide and Petrulionè compared the masculine anthroponyms in Brazil with the masculine anthroponyms in Lithuania based on statistical data available on institutional sites and with consideration of the linguistic, historical and cultural characteristics of each country, including the migration process of Lithuanians to Brazil from the beginning to the middle of the last century (cf. Seide/Petrulione 2018). Also, linking anthroponyms and migration, Seide investigated the linguistic characteristics and the repertoire of names given to descendants of Lithuanians in Brazil based on a sample of names from a Facebook closed group created for descendants of Lithuanians in Brazil (cf. Seide 2018c).

Another emerging research sub-area in Brazil is dedicated to unofficial anthroponymy, i. e. names that are not part of the official civil registry. While Amaral and Machado investigated 
names of candidates and city councilors ${ }^{8}$ taking part in the Municipal Chamber (from 1989 to 2013) of the government of Ouro Preto, a municipality in the state of Minas Gerais, in southeastern Brazil (cf. Amaral/Machado 2015), Camargo (2018) dedicated herself to the use of pseudonyms and heteronyms by a Portuguese journalist and a Brazilian journalist, respectively Cid Martins (a Jornal Zero Hora columnist) and António Sousa Homem (a Portuguese chronicle writer who publishes in the Jornal correio da manhã).

It should be noted that all anthroponomastic investigations that focus on the anthroponymic description - including both those that describe anthroponymic repertoires and those that are also concerned with the description and analysis of naming process - propose interdisciplinary analyses that relate, or make reflections on the relations between language and society, and belong to the subfield of the socioanthroponomastics. Another markedly interdisciplinary subfield is fictional anthroponomastics.

The studies on this subfield, focus on the investigation of the literary function and the semantic and etymological load of the names of characters of renowned Brazilian writers. Whereas Da$\mathrm{vid} /$ Siqueira (2014) analyzed the function of the appointment in the short story Joãoboi by Bernardo Élis, Eckert and Röhring (2016a and 2018) analyzed the anthroponymic literature in the novel Ubirajara by José de Alencar and in the novels Vidas Secas and São Bernardo by Graciliano Ramos.

In addition to the empirical research already mentioned, there are investigations that provide methodological contributions and/or literature review to the Brazilian public. We can find reflections on the different paradigms adopted in Brazil when it comes to analyzing toponyms and anthroponyms (cf. Seide 2013a), an international literature review for the description of areas of anthroponomastic research (cf. Seide 2016b), a review about neological first names in Brazil (Simões Neto/Santos 2017) and an essay on the validity of small scale quantitative methodologies for the study of anthroponymic trends (cf. Seide 2017).

Research papers that make theoretical contributions to the area of anthroponomastics have also been published in Brazil (cf. Amaral 2011, Henriques 2015, Seide/Schultz 2014, Frai, 2016b). Henriques (2015) analyzed Saussure's manuscripts to elucidate how the linguist proposed the analysis of proper names and discovers that he believed that proper names are signs distinct from common nouns, because when speakers come across a proper name they will have more awareness of the referent to which such name refers. Amaral proposed a typology suitable for the anthroponymy of the Brazilian Portuguese language, while Seide/Schultz (2014) applied the assumptions of the Relevance Theory (cf. Sperber/Wilson 2001) to the analysis of anthroponyms and toponyms formed by anthroponyms to evidence how associative meaning of names might be formed in the speakers' awareness during language use. Frai (2016b), in turn, put forward the socio-onomastics field to Brazilians.

\footnotetext{
${ }^{8}$ In Brazil, politicians can choose a special name to run for election and during the period they work as city couuncilors, senators or representatives. This name differs from their civil name and is similar to a nickname.
} 


\section{Other studies devoted to personal names}

Proper names are part of languages and can be studied from various points of view: phonetic, morphological, syntactic, pragmatic, among others. In the present day in Brazil it is consensual that linguistic studies on place names are object of toponomastic studies. While many researchers focus on personal names in their analyses, they do not affiliate their research to anthroponomastic studies. This means that a literature review on the issue would be incomplete if the investigation were limited to articles indexed by the most used key words on the field. So adoption of a broader perspective was necessary. In all studies considered here there is none or very few mentions to onomastics terminology along the articles.

Massini-Cagliari (2011) investigated how phonological adaptations of foreign first names in the Portuguese language, contemporaneously used by Brazilian Portuguese speakers occurred and made a comparison among such processes and how, hypothetically, phonological adaptations of foreign first names mentioned on the Cantigas de Santa Maria ${ }^{9}$ would have happened.

Focusing on the phono-morphological and morphological levels of linguistic analysis, there are investigations by Gonçalves (2004) and Lima (2017). The first researcher defended the regularity of the hypocorization process of anthroponyms in Brazilian Portuguese with regard to prosody and the interface between morphology and phonology. The second took up the hypothesis of Gonçalves and applied it to the analysis of abbreviating processes of compound anthroponyms. Although Lima and Gonçalves, unlike Massini-Cagliari, use the technical terms of the field (anthroponym and hypocoristic), there is no mention of Onomastics or any citation of researchers of the area, while Lima indexed his article with the following keywords: hypocorization, morphology, phonology, theory of optimality ${ }^{10}$. None of the above mentioned authors are researchers in the field of anthroponomastics.

In the field of sociolinguistics, articles on the variable use of the definite article before proper names in different regions of Brazil have been published in order to clarify not only in which regions this phenomenon occurs more frequently, but also which extralinguistic or sociological variants condition this process (cf. Campos Junior 2012, Mendes 2017, Sedrins et al. 2017, Pereira/Silva, 2018).

Campos Junior (2012) investigated this phenomenon in Vitória, capital of the state of Espírito Santo, in northeastern Brazil, and uses the technical term anthroponym, but did not mention it among the keywords of the article, did not affiliate the research in anthroponomastics, nor did he cite authors in the field.

Sedrinset al. (2017) analyzed the same phenomenon in two cities of the state of Pernambuco, Caranaíba and Serra Talhada, in the northeastern region of the country. Pereira/Silva (2018) focused on the linguistic attitudes of residents of Serra Talhada with respect to the use of definite articles with first names. From a diachronic perspective, Mendes (2017) investigated the uses of definite articles in two cities of Minas Gerais (the state of Minas Gerais is part of the southeastern region of the country): Abre Campo and Matipó in the period from 1875 to 1950.

\footnotetext{
9 This collection comprises cantigas (songs) in praise of the Virgin Mary, with musical notation, ordered to be compiled by Afonso o Sabio, King of Castile in the second half of the XIII century (Massini-Cagliari 2011: 801). ${ }^{10}$ In Gonçalves, there are no keywords indexing the article.
} 
In all the cited articles, the term anthroponym appears among the keywords, but there was no mention to researchers of the field, nor affiliation of the research with anthroponomastics.

Carvalho (2017), in turn, focuses on the region of Belo Horizonte, capital of the state of Minas Gerais. In her article, she presents part of her master's thesis defended at the Federal University of Minas Gerais. The term anthroponym appeared as a keyword and the author cited two researchers from the field of onomastics, Seabra and Amaral, but her research was not affiliated with anthroponomastics, but rather with sociolinguistics.

Dias/Farias (2017), finally, studied the phenomenon in the cities of Ponte Nova and Ouro Branco. The term anthroponym also appeared as a keyword. Amaral is cited and, unlike those studies mentioned so far, there was discussion about the definition and classification of anthroponyms based on Amaral's (2011) research. Notwithstanding, there was no affiliation of the research to anthroponomastics.

In all cited papers dealing with the use of the definite article, research is exclusively affiliated to the field of sociolinguistics in general and of variationist sociolinguistics in particular. There seems to be unawareness of the potentially interesting work going on in the neighboring disciplines of sociolinguistics and anthroponomastics.

Some other potential interesting work across disciplines can be found on the studies on fictional anthroponymy. Queiroz (2015) analyzed the anthroponyms in the novel Terras do Sem Fim by Jorge Amado and, although using this technical term in the title, as a keyword and in the body of the article, he made no mention of anthroponomastics or onomastics, nor does he mention any researcher in the field. The same happened with Câmara (2013). She used the term anthroponym as a keyword in her article in which she analyzed three novels by Machado de Assis: Memórias Póstumas de Brás Cubas, Quincas Borbas and Dom Casmurro.

This lack of recognition of anthroponomastics also occurred on Silva's (2016) research on the translation from the Spanish language to the Portuguese language of fictional anthroponyms in the comic strips Mafalda.

\section{$5 \quad$ Final remarks}

In order to gather recent onomastic investigations developed in Brazil, in view of their dissemination to a wider public, the literature review presented in this article portrays current research in the area. It has been observed that in the field of toponomastics there is a certain uniformity arising from the hegemony of the paradigm proposed by Dick (cf. Seide 2013a) and the development of projects dedicated to the elaboration of toponymic atlases in several regions of the country: in the Amazon (cf. Souza 2008), in Tocantins (cf. Andrade 2010), Maranhão (cf. Castro 2017), São Paulo (cf. Dick 2004), in Bahia (cf. Zamariano 2018, Abade 2016), Goiás , Mato Grosso do Sul, Minas Gerais, and Paraná (cf. Zamariano 2012).Following, there is a brief comparison of studies mentioned in this paper to Europeans researches in Onomastics.

In Europe, the first etymological studies of proper names made throughout the twentieth century were developed. More recently some concern for the study of name uses in society was raised. These studies "draws on techniques from sociolinguistics and has gradually been gathering momentum over the last few decades". Conducting research in this view resulted in the creation of an emerging research field: socio-onomastics. "The emerging subdiscipline of socio- 
onomastics offers new approaches to names of all kinds, including both personal names and place names". In addition, due to extensive database availability, more comparative research has been done. Another recent paradigm has arisen in the area of toponymic studies with the emergence of studies on linguistics landscape research: "an approach that has emerged in recent years to reflect issues relating to the language(s) used on public signs (...) in areas occupied by different speech communities" (Hough 2016: 9). Other areas of onomastic studies cited by Hough are onomastic theory, literary onomastics, onomastics and other disciplines, and other names (aircraft names, animal names, astronomical names, names of dwellings, railway locomotive names, train names, ship names).

The comparison of the research described in this review with onomastic studies in Europe described by Hough (2016) reveals that the fields that Hough evaluated as emergent are also emergent in Brazil. There are studies that relate the studies of the linguistic landscape with toponymic studies (cf. Lucas 2018, Seide/Lucas/Teis 2018, Seide 2018a) and socio-anthroponomastic investigations based on data collection in written documents (cf. Eckert 2013, 2016, 2017, Eckert/Röhrig 2016b, Grespan 2014, Vescovi 2014, 2015, 2016, Seide/Grespan 2013, Seide 2014, 2018b), or data collection through field research (cf. Frai 2016a, Seide 2013b, 2013c, 2016a). There was also comparative anthroponymic research (cf. Cardoso 2018, Seide 2018c, Seide and Petrulionè 2018).

As in the collection organized by Hough, there are, in Brazil, investigations that deal with theory, (cf. Amaral 2011, Henriques 2015, Seide/Schultz 2014) methodology (cf. Seide, 2013a, Seide, 2017) and literature review in the area (cf. Seide 2016b).

Some Brazilian investigations, however, are distinct. There are no investigations in Brazil on the category of other names (aircraft names, animal names, astronomical names, names of dwellings, railway names, train names, ship names), and there are some types of personal names that are not mentioned in the book organized by Hough, namely, the research on Brazilian city councilor names (Amaral/Machado 2015) and the studies on anthroponymy of the indigenous languages of Brazil (Ferreira 2018, Dias 2018, Fargetti 2018, Falchi/Aguiar 2018, Martins et al. 2018).

Another particularity of the Brazilian academic environment is the non-recognition of onomastics and socio-onomastics by some linguists (cf. Campos Junior 2012, Carvalho 2017, Dias/Farias 2017, Gonçalves 2004, Lima 2017, Massini-Cagliari 2011, Mendes 2017, Pereira/Silva 2018, Sedrins et al. 2017). It should be noted that, from a theoretical and methodological point of view, the researchers mentioned above might as well be affiliated with socio-onomastics.

The same phenomenon was observed for fictional anthroponomastics. There are researches affiliated to the field (cf. David/Siqueira 2014, Eckert/Röhring 2016, 2018) and researches that are based only on literature (cf. Camara 2013, Queiros 2015, Silva 2016). Likewise, no substantial differences were observed between investigations of fictional names affiliated with anthroponomastics and those who do not affiliate with the field.

Such lack of awareness concerning anthroponomastics may be related to the fact that Guérios, in spite of having contributed to the field, did not train generations of researchers because, during the time while he taught at the university, there was no post-graduation degrees offered in linguistics. Thus it is believed that these cases of non-affiliation are consequences of the 
unequal way by which the branches of onomastic studies were introduced in Brazil. This difference resulted in dispersion and fragmentation of anthroponymic studies that contrast with the consolidation of a paradigm of research and a cohesive group of researchers in the field of toponomastics.

\section{References}

Abade, Celina Márcia de Souza (2016): “Atobah: proposta de elaboração do atlas toponímico". Caletroscópio 4: 576-588. caletroscopio.ufop.br/index.php/caletroscopio/article/viewFile/ 157/104 [21.03.2019].

Andrade, Karylleila dos Santos (2010): "Projeto Atito: algumas considerações sobre o Atlas Toponímico de Origem Indígena do Estado do Tocantins". In: Isquerdo, Aparecida Negri/ Finatto, Maria José B.(eds.): As ciências do Léxico. Lexicologia, Lexicografia, Terminologia. Vol. IV. Campo Grande, UFMS:133-144.

Aldrín, Emilia (2017): "The choice of first names as a social resource and act of identity among multilingual families in contemporary sweden”. In: Ahrens, Wolfgang/Embleton, Sheila/Lapiere, André (eds.): Names in Multilingual, Multi-cultural and Multi-ethnic Contact. Proceddings fo the $23^{\text {rd }}$. International Congress of Onomastic Sciences. August 17-22, 2009, York University. University of Toronto, Canada.

Almeida, Aurelina Ariadne Domingues (2015): “Contribuições de José Pedro Machado para o conhecimento da história da antroponímia do português do Brasil". Filologia e Linguística, 17/2: 309-331. revistas.usp.br/flp/article/download/89623/111821 [21.03.2019].

Amaral, Eduardo Tadeu Roque (2011): “Contribuição para uma tipologia de antropônimos do português brasileiro". Revista Alfa 55/1: 63-82.

Amaral, Eduardo Tadeu Roque/Machado, Verônica Barçante (2015): "Nomes de urna e nomes parlamentares de vereadores da Câmara Municipal de Ouro Preto sobre nomes secundários". GTLex 1/1: 52-65. seer.ufu.br/index.php/GTLex/article/view/31721/17880 [21.03.2019].

Câmara, Tania Maria Nunes de Lima (2013): "Hipocorísticos, apelidos e crítica social: linguagem e estilo em Machado de Assis", Matraga 20/32: 208-220. e-publicacoes.uerj.br/index.php/matraga/article/view/19849 [21.03.2019].

Camargo, Amanda Kristensen de (2018): "Pseudônimos e heterônimos na esfera jornalística contemporânea”. Temática, 14/10:.203-218. periodicos.ufpb.br/ojs/index.php/tematica/ article/view/42303 [21.03.2019].

Campos Junior, Heitor da Silva (2012): “A variação morfossintática do artigo definido na capital capixaba”. Percursos Linguísticos, 2/5: 22-29. periodicos.ufes.br/percursos/ article/view/3178 [21.03.2019].

Cardoso, Guilherme Lima. (2018): “O paradoxo onomástico entre jesuítas e indígenas no Brasil do século XVI”. In: Aguiar; Castro (ed.): Onomástica e a Identidade do Homem. Goiânia, Editora Imprensa Universitária: 401-431.

Carvalhinhos, Patrícia de Jesus/Lima, Adriana Tavares (2018): “Toponymic Inflation: When the Politics Dilates Names. The Bridges of São Paulo (São Paulo, Brazil) ". Onomastica Uralica, 12: 405-414. mnytud.arts.klte.hu/onomural/kotetek/ou12a.html [25.03.2019].

Carvalhinhos, Patrícia de Jesus/Lima, Adriana Tavares (2013): "Denominaciones en el espacio público brasileño: algunas palabras sobre São Paulo". Rivista Italiana di Onomastica, XIX: $605-632$. 
Carvalhinhos, Patrícia de Jesus/Lima, Adriana Tavares (2014): "Espacios públicos de São Paulo (Brasil): sus denominaciones". Revista Trama (Cascavel. Impresso) 10: 45-52.

Carvalhinhos, Patrícia de Jesus/Lima-Hernandes, Maria Célia/Lima, Adriana Tavares (2018): "The ideological function in names of public spaces in the city of Sao Paulo, Brazil." Onomastica Uralica 14: 93-110.

Carvalho, Ana Paula Mendes de (2017): “O comportamento linguístico dos jovens de Barra Longa/MG”. Caletroscópio 5/8: 69-90. caletroscopio.ufop.br/index.php/caletroscopio/ article/view/237 [21.03.201].

Castro, Mária Célia Dias de (2017): “Atlas toponímico do estado do Maranhão: uma proposta de análise da macrotoponímia”. Caderno Seminal Digital, 28/01: 110-147.

David, Nismaria Alves/Siqueira, Quênia Mara de Freitas (2014): "A nomeação do ser no processo narrativo: uma leitura do conto Joãoboi, de Bernardo Élis”, Guavira Letras 18: 3652. websensors.net.br/seer/index.php/guavira/article/view/51/36 [21.03.2019].

Dauzat, Albert (1934): Les noms de personnes: origine et évolution (prénoms, noms de famille, surnoms, pseudonymes). Paris: Delagrave.

Dauzat, Albert (1945): Les Noms de Famille de France. Paris: Payot.

Dauzat, Albert (1951): Dictionnaire Étymologique de Noms de Famille et de Prénoms de France. Paris: Larousse.

Dias, Ana Lourdes Cardoso (2018): “Antropônimos: interação linguística e sociocultural”. In Aguiar; Castro (ed.): Onomástica e a Identidade do Homem. Goiânia, Editora Imprensa Universitária: 237-274.

Dias, Melina Rezende/Faria, Glauciane da Conceição dos Santos (2017): “O artigo definido diante de antropônimo: um estudo comparativo entre as cidades mineiras de Ponte Nova e Outro Branco". Caletroscópio, 5/8: 51-68. caletroscopio.ufop.br/index.php/caletroscopio/ article/view/193 [21.03.2019].

Dick, Maria Vicentina do Amaral (1992): Toponímia e antroponímia no Brasil. Coletânea de Estudos. $3^{\text {rd }}$ ed. São Paulo: Serviço de Artes Gráficas da Faculdade de Filosofia, Letras y Cieências Humanas/USP.

Dick, Maria Vicentina do Amaral (2004) : "Rede de conhecimento e campo lexical: hidrônimos e hidrotopônimos na onomástica brasileira”. In: Isquerdo, Aparecida Negri/Krieger, Maria da Graça (eds.): As Ciências do Léxico, Lexicologia, Lexicografia, Terminologia. Vol II. Campo Grande/Brasil, Ed. UFMS: 121-131.

Eckert, Kleber (2013): "Quem é quem? Um estudo antroponímico a partir dos sobrenomes do município de Lajeado-RS”. Domínios de Lingu@gem 7/1: 139-159. doi 10.14393/DL13v7n1a2013-8.

Eckert, Kleber (2016): "Os sobrenomes dos alunos do IFRS, campus Bento Gonçalves: um estudo onomástico". Domínios de Lingu@gem 10/1: 46-66. doi 10.14393/DL21v10n1a2016-3.

Eckert, Kleber (2017): "Os nomes dos alunos do IFRS - Campus Bento Gonçalves: um estudo onomástico”. Revista de Educação, Ciência e Tecnologia. 6: 1-18. doi 10.35819/ tear.v6.n1.a2045.

Eckert, Kleber/Röhrig, Maiquel (2016a): “Antroponímia ficcional: o caso de Ubirajara, de José de Alencar”. Revista GTLex. 2/1: 170-189. doi 10.14393/Lex3-v2n1a2016-7. 
Eckert, Kleber/Röhrig, Maiquel (2016b): “Os sobrenomes dos habitantes de Estrela-RS: um estudo onomástico”. Caletroscópio 3/5: 61-85. caletroscopio.ufop.br/index.php/ caletroscopio/article/view/65 [21.03.2019].

Eckert, Kleber/Röhrig, Maiquel (2018): “Onomástica literária em Graciliano Ramos: os nomes dos personagens de Vidas Secas e de São Bernardo". Revista de Estudos da Linguagem 26/3: 1277-1294. periodicos.letras.ufmg.br/index.php/relin/article/view/12826 [21.03.2019].

Falchi, Flávia Leonel/Aguiar, Maria Suelí (2018): "Distribuição mitológica de antropônímos no Noke Koin". In Aguiar/Castro (eds.): Onomástica e a Identidade do Homem. Goiânia, Editora Imprensa Universitária: 301-338.

Fargetti, Cristina Martins (2018): “Questões sobre a antroponímia Juruna”. In Aguiar/Castro (ed.): Onomástica e a Identidade do Homem. Goiânia, Editora Imprensa Universitária: 275-300.

Frai, Patricia Helena (2016a): Motivação para a escolha de um segundo nome na antroponímia rondonense. UNIOESTE, PPGL, Cascavel (masther tesis).

Frai, Patricia Helena (2016b): "Sócio-Onomástica: uma nova abordagem metodológica". Entreletras, 7/1: 91-106. https://sistemas.uft.edu.br/periodicos/index.php/entreletras/ article/download/2028/pdf/. [21.03.2019].

Gonçalves, Carlos Alexandre (2004): "A morfologia prosódica e o comportamento transderivacional da hipocorização no português brasileiro", Revista de Estudos da Linguagem, 12/1:7-38. periodicos.letras.ufmg.br/index.php/relin/article/ view/2373/2327 [04.07.2019].

Guérios, Rosário Farâni Mansur (1981): Dicionário Etimológico de nomes e sobrenomes. São Paulo: Ave Maria.

Grespan, Taiana (2014): Antroponímia de Toledo - Paraná - 1954-2004: aspectos inovadores. Unioeste, PPGL, Cascavel (masther tesis).

Henriques, Stefania Montes (2015): "Sobre teoria antroponímica”.Revista Argentina de Historiografia Linguística:7/1: 31-38.

Hough, Carole (2016): The Oxford handbook of names and naming. Oxford University Press.

Lima, Bruno Cavalcanti (2017): "A hipocorização como processo não concatenativo de formação de palavras em português: a interface morfologia-fonologia em destaque" Domínios da Lingu@gem, 11/3: 782-803. seer.ufu.br/index.php/dominiosdelinguagem/ article/view/37301 [21.03.201].

Lopes, Tereza Tayná Coutinho/Ferreira, Marília de Nazaré de Oliveira (2018): “Onomástica Parkatêjê: aspectos semânticos dos nomes próprios de pessoas". Revista de Estudos da Linguagem, 26/3: 1177-1200. periodicos.letras.ufmg.br/index.php/relin/article/ download/12676/pdf_1 [21.03.2019].

Lucas, Patricia(2018): Nomes Comerciais em Naranjal - Paraguai. Cascavel, UNIOESTE, PPGL, Cascavel (masther tesis).

Machado, José Pedro (1981/2003): Dicionário onomástico etimológico da língua portuguesa. Lisboa: Horizonte/Confluência.

Mariano, Victor Cavalcanti (2013): “A antroponímia dos matriculados na sociedade protetora dos desvalidos durante a segunda década do século XX”. Entre Palavras: 3/1: 199-217. entrepalavras.ufc.br/revista/index.php/Revista/article/view/161 [21.03.2019]. 
Martins, Andérbio Marcio Silva et al. (2018): “Antroponímia Kaiowá”. In Aguiar/Castro (eds.): Onomástica e a Identidade do Homem. Goiânia: Editora Imprensa Universitária: 339-400.

Massini-Cagliari, Gladis (2011): "Adaptação fonológica de nomes próprios de origem estrangeira: comparação entre Português Arcaico e Português Brasileiro". Estudos Linguísticos 40/2: 795-807. revistas.gel.org.br/estudos-linguisticos/article/view/1340 [21.03.2019].

Mendes, Andreia Almeida (2017): "A variação sintática do artigo definidio diante de antropônimos em Abre Campo e Matipó: dados de língua escrita pretérita”. Caletroscópio, 5/8:34-50. caletroscopio.ufop.br/index.php/caletroscopio/article/view/232 [21.03.2019].

Mill, John Stuart (1872): A system of Logic. Ratiocinative and Inductive. London: Longmans.

Nolasco, Daniele de França/Hosokawa, Antonieta Buriti de Souza (2012): "O estudo das origens dos nomes de pessoas através dos manuscritos do acervo Guiomard Santos". Revista Philologus 18/54: 479-490. filologia.org.br/rph/ANO19/55SUP/039.pdf [21.03.2019].

Pereira, Dérech K. Ferreira/Silva, Cláudia Roberta Tavares (2018): “As atitudes linguísticas de serratalhadenses sobre a realização de artigo definido diante de antropônimos". Interdisciplinar - Revista de Estudos em Linguagem, 28: 109-131. seer.ufs.br/index.php/interdisciplinar/article/view/9628 [21.03.2019].

Queiroz, Rita de Cássia Ribeiro de (2015): "Nomes e sobrenomes: a antroponímia em Terras do Sem Fim, Romance de Jorge Amado". Revista Philologus, 21/63: 130-138. filologia.org. br/rph/ANO21/63/011.pdf [21.03.2019].

Rodrigues, Letícia Santos/Coelho, Juliana Soledade Barbosa (2016): “Germanismos e a contribuição para a antroponímia brasileira". Revista Hyperion 8: 75-90. portalseer.ufba.br/ index.php/revistahyperion/article/view/17018 [21.03.2019].

Sacerdote, Irani Souza (2012): “Antroponímia portuguesa: um breve estudo acerca dos sobrenomes no período medieval". Voos Revista Polidisciplinar Eletrônica da Faculdade de Guaicará 4/1: 31-40. revistavoos.com.br/seer/index.php/voos/article/viewArticle/281 [21.03.201].

Seabra, Maria Cândida Trindade da Costa de/Isquerdo, Maria Aparecida Negri (2018): "Onomastics in Different Perspectives: Research Results". Revista de Estudos de Linguagem 26/2: 993-1000. periodicos.letras.ufmg.br/index.php/relin/article/view/13700/pdf_1 [21.03.2019].

Sedrins, Adeilson Pinheiro et al. (2017): "O uso do artigio definido diante de antropônimos e pronomes possessivos em duas cidades do sertão pernambucano". Caletroscópio 5/8: $12-33$.

Seide, Márcia Sipavicius (2013a): “Toponomástica e Antroponomástica: paradigmas e métodos". Confluencia 44/45: 165-184. 1lp.bibliopolis.info/confluencia/wp/?cat=32 [21.03.2019].

Seide, Márcia Sipavicius (2013b): "Motivações contemporâneas para a escolha do antropônimo". Entre Letras 4/2: 90-101. sistemas.uft.edu.br/periodicos/index.php/ entreletras/article/download/992/531 [21.03.2019].

Seide, Márcia Sipavicius (2013c): "Estudio exploratorio". Multidisciplina 16: 116-138. revistas.unam.mx/index.php/multidisciplina/article/view/50082 [21.03.2019].

Seide, Márcia Sipavicius (2014): "Nome próprio e identidade". Revista Estudos Linguísticos 43/1: 212-225. revistas.gel.org.br/estudos-linguisticos/article/view/432 [21.03.2019]. 
Seide, Márcia Sipavicius (2016a): "A identidade religiosa na antroponímia de Marechal Cândido Rondon”. Revista de Estudos da Linguagem 24/1, 2016: 333-352. periodicos.letras. ufmg.br/index.php/relin/article/viewFile/6310/8850 [21.03.2019].

Seide, Márcia Sipavicius (2016b): "Métodos de pesquisa em Antroponomástica” Domínios de Lingu@gem 10/3: 1146-1171. seer.ufu.br/index.php/dominiosdelinguagem/article/view/ 32482 [21.03.2019].

Seide, Márcia Sipavicius (2017): “Comparabilidade de corpora díspares”. Estação Científica 7/3: 83-93. periodicos.unifap.br/index.php/estacao/article/view/3668 [21.03.2019].

Seide, Márcia Sipavicius (2018a): "Nomeação e territorialização". Revista Fórum Identidades 26/26: 161-178. seer.ufs.br/index.php/forumidentidades/article/view/9180 [21.03.2018].

Seide, Márcia Sipavicius (2018b): "Moda e tradição na antroponímia". In: Isquerdo, Aparecida, Negri/Dal Corno, Giselle/ Mantovani, Olivia (eds.): As Ciências do Léxico. Lexicologia, Lexicografia, Terminologia. Vol. VIII, 2018. Campo Grande, Ed. UFMS: 149-166.

Seide, Márcia Sipavicius (2018c): "Antroponímia e migração: os nomes de brasileiros descendentes de lituanos". WebRevista Sociodialeto 7/21: 52-81. sociodialeto.ojs.galoa.com.br/index.php/sociodialeto/article/view/55 [21.03.2019].

Seide, Márcia Sipavicius/Frai, Patricia Helena (2015): "Motivações para a escolha de nomes duplos". In: Fargetti, Cristina Martins/Murukawa, Clodilte de Almeida Azevedo /Nadin, Odair Luiz. (eds.): Léxico e Cultura. Araraquara, Letraria: 15-24.

Seide, Márcia Sipavicius/Grespan, Taiana (2013): "Mais Wellicas Samaras e Hendryas Nicoles, menos Marias Luízas e Joões Pedros: Os novos nomes duplos do sistema antroponímico brasileiro". Recorte 10/2: 1-19.

Seide, Márcia Sipavicius/Lucas, Patricia/Teis, Denize Teresinha (2018): "Os topônimos na paisagem linguística”. Revista do Gelne 20/2: 16-29. periodicos.ufrn.br/gelne/article/view/ 14089 [25.03.2019].

Seide, Márcia Sipavicius/Lolita, Petrulionè (2018): "Between Languages and Cultures: na Exploratory Compartive Stuy of Usage of Lithuanian and Brazilian Masculine Anthroponyms". Revista Estudos da Linguagem, 26/3: 1201-1226. periodicos.letras.ufmg.br/index.php/relin/ article/view/12745 [24.03.2019].

Seide, Márcia Sipavicius/Schultz, Benilde Scropeba (2014): "Linguagem, Cognição e Identidade”. In: Isquerdo, Aparecida N./Dal Corno, Giselle O. M. (eds.): As Ciências do Léxico. Lexicologia, Lexicografia, Terminologia. Vol. VII. Campo Grande, Ed. UFMS: 149-166.

Silva, Bárbara Zocal da (2016): “As traduções dos nomes próprios nas histórias em quadrinhos: um estudo de caso das tiras de Mafalda, de Quino". Tradterm, 27: 155-179. revistas. usp.br/tradterm/article/view/121377 [21.03.2019].

Simões Neto, Natival Almeida/Rodrigues, Letícia Santos (2017): “A neologia e os processos genolexicais em antropônimos brasileiros: um breve mapeamento de estudos realizados". Mandinga - Revista de Estudos Linguísticos 1/2: 110-127. revistas.unilab.edu.br/index. $\mathrm{php} / \mathrm{mandinga/article/view/33} \mathrm{[21.03.2019].}$

Sacerdote, Irani Souza (2012): “Antroponímia portuguesa: um breve estudo acerca dos sobrenomes do período medieval". Voos Revista Polidisciplinar Eletrônica da Faculdade de Guaicará 4/1: 31-40. revistavoos.com.br/seer/index.php/voos/article/viewArticle/281 [02.07.2019]. 
Sperber, Dan/Wilson, Deirdre (2001): Teoria da Relevância: comunicação e cognição. Alves, H. A. (trad.) Lisboa: Fundação Calouste Bulenkian, 2001.

Souza, Alexandre Melo de (2008): "Projeto Atlas Toponímico da Amazônia Ocidental Brasileira: gênese e trajetória”. Ícone 2: 31-42. revista.ueg.br/index.php/icone/article/view/ 5126/3397 [21.03.2019].

Vasconcellos, José Leite de (1928): Antroponímia portuguesa: tratado comparativo da origem, significação, classificação, e vida do conjunto dos nomes próprios, sobrenomes, e apelidos, usados por nós desde a Idade Média até hoje. Lisboa: Imprensa Nacional.

Vescovi, Jéssica Paula (2014): "Escolha dos nomes de pessoas pelos pioneiros de PalotinaPR”. Estudos Linguísticos 43/1: 201-211. revistas.gel.org.br/estudos-linguisticos/article/ download/431/313 [21.03.2019].

Vescovi, Jéssica Paula (2015): Prenomes e sobrenomes em Palotina-PR e em Maripá-PR: um estudo comparativo. UNIOESTE, PPGL, Cascavel (Master thesis).

Vescovi, Jéssica Paula (2016): "O impacto da era da hortelã no sistema antroponímico de Palotina e Maripa (PR)”. Entre Letras 7/2: 164-177. sistemas.uft.edu.br/periodicos/index. php/entreletras/article/download/2946/9486/ [21/03/2019].

Zamariano, Márcia (2012): “Cartografação dos dados toponímicos no Brasil: perspectiva historiográfica”. Revista do Gelne 14: 77-98. periodicos.ufrn.br/gelne/article/view/9384. 